\title{
Historical aspects of production of swine breeding of Ukraine in the Soviet period
}

\author{
M. Ibatullin, \\ Candidate of Sciences (Economics) \\ National University of Life and Environmental Sciences of Ukraine
}

The purpose. To assess operation of swine breeding as a branch in the Soviet period and on the basis of generalization of that experience to offer practical recommendations on overgrowth of volumes of production in present time. Methods. Abstract-logical, statistical observation, comparison, statistical series, expert assessments. Results. It is fixed that during 1917 - 1991 in Ukraine the swine breeding developed in two directions: industrial - in collective farms and state farms, and personal - in personal peasant farms. It is fixed that in the midpoint of 1970th almost each neighbouring commune has $1-2$ specialized pig-growing farms, and in some oblasts industrial complexes with the complete cycle of fattening. Conclusions. In the post-war period the swine breeding became one of branches of anima I husbandry that ensured all classes of the population with meat food. The basis of scientific development of this branch which integrator was Research institute of swine breeding is included. However, because of negative aftereffects of agrarian reform industrial production of products of swine breeding has actually been destroyed, and personal peasant farms are oriented exclusively on self-provision.

Key words: swine breeding, production, consumption, collective farms, personal farms.

Pork belongs to the most economically efficient and "fastest" branches of animal husbandry, which is due to the biological characteristics of animals. Pork is one of the most important subsectors of animal husbandry, which provides people with high-protein and dietary food.

The pig products market occupies a special place in the meat and meat products market and significantly influences the nature of the reproductive process throughout the meat product subcomplex. Pork and products of its processing are of great importance for the population to provide food, while processing industries are raw materials, that is, in the formation of food security of the country.

Analysis of recent research and publications. Problems concerning the formation and functioning of the pork market have not yet been widely reflected in the national scientific literature.

Separate scientific intelligence in this regard was carried out by T.V. Aleksiychuk, MP Talavir, OI Khristenko Considerable attention in the context of this problem deserves work devoted to market reform and formation of agricultural products markets (authors: PS Berezivsky, TG Dudar, SL Dusanovsky, MV Kalinchik, MV Kuzubov, II Lukinov, MI Malik, SI Mikhailov, VG Poplavsky, P. T. Sabluk, AM Stelmashchuk, M. Y. Khorunzhy, O. M. Shpichak, V. V. Yurchyshyn, IG Yaremchuk, etc.).

The purpose of the research is to evaluate the functioning of pig production as an industry in the Soviet period and, based on the generalization of experience, to offer practical recommendations for increasing production volumes at the present time.

Material and methods of research. To achieve this goal, the following methods were used: abstractlogical, statistical observation, comparison, statistical series, expert evaluations.

Research results. After dramatic events, the establishment of the Bolshevik authorities in Ukraine, even in the context of a certain liberalization in the politics and economy of the NEP period, did not materially improve the life of the Ukrainian peasantry. Consequently, the development of pig breeding had a relative character (full satisfaction with pork was considered a kind of indicator of the well-being of the peasant's life). Particularly difficult were the 1921-1922 biennium - the years of famine, fleeing from which the peasants cut cattle, primarily pigs. According to statistics, two-thirds of the peasants were forced to save their cows (their nurses) during the winter of 1921-1922 to feed them with straw from the bark, dry 
leaves and other surrogates [4]. Pigs that needed more essential food (roots, potatoes, etc.), of course, did not withstand competition with cattle. Compared to 1916 (the last pre-revolutionary year for which statistical information was preserved) in 1922 the number of bovine animals decreased by 20,8\%; sheep and goats - by 5.8 , pigs - by $83.8 \%$ [1]. Moreover, the mass cutting of the pigs population occurred in Saama because of the famine of 1921 - 1922, which makes it possible to assert the statistics of the ratio of the indicators of spring 1922 compared with the spring of 1921. If you accept the stock of pigs in the spring of 1921 for $100 \%$, then in the spring of 1922 they remained: in the Donetsk region - $22 \%$, Odessa region - 20, Mykolaiv region - 13, Ekaterinoslav region - 10, in Zaporozhye - 7\% [1].

The situation in pig breeding began to improve since 1923, when the pig population in Ukraine was approximately $55 \%$ of the level of 1916. As early as 1924, the level of 1916 was achieved, in 1928 (the most successful in economic terms, on the eve of the rally "The" class struggle against the enemies of the Soviet government "-" kulaks ") the number of pigs reached 134\% from the level of $1916-5.75$ million goals. [8]. Moreover, $99 \%$ of the pig population was kept at the same time in individual farms [1]. However, already in 1929, with the onset of tax pressure on wealthy peasant farms, livestock decreased by $40 \%$ and amounted to 3.44 million goals. [1].

According to the census of the population, held in December 1926, 29.02 million people lived in Ukraine. [2]. If we use the same methodology of calculations used by the statisticians of the Russian Empire, we will have the same ratio in Ukraine as in 1928, which was in the most prosperous provinces of imperial times - for 100 souls of the population about 20 goals. pigs However, with the start of disposals, already in 1929, this figure was reduced to approximately 12 goals. pigs for 100 people.

It is important to note that, as of 1927 , farms in Ukraine, which comprised $23.7 \%$ of the farms of Ukraine, belonged to the peasant farms that were classified as poor (those who had no means of production at all or had up to 200 rubles in the yard). Such peasants held about $8.4 \%$ of the total pig population. Average farms (those that had production facilities in the amount of $201-1600$ rubles per yard) accounted for $72.3 \%$ of farms and they accounted for $80.5 \%$ of the pig population. The wealthy ("kulaks") were considered $4 \%$ of the farms (with means of production for the amount of more than 1600 rubles per yard), they held $11.1 \%$ of the pig population [1].

The nature of fattening pigs kept all pre-revolutionary features. In the Ukrainian Right Bank and the Left Bank, the feed base was made up of waste from sugar refineries and spirits (molasses, pulp, grains).

So, the marketability of pig breeding here was the highest. On the Right Bank it reached $21 \%$, on the Left Bank - 36\%. Instead, in the Ukrainian Polissya, pig breeding was kept in a natural-consumer way; in the absence of a proper feed base, pigs were kept on natural lands - on meadows and forest pastures, in an extremely primitive care culture. Therefore, the animals were characteristic of late-penile, small weight, low fertility, and therefore the marketability reached only $6-11 \%$ [1].

In general, the pig industry in Ukraine in the 20's can not be called highly effective. The slaughter weight of pigs (according to the data of 1926 - $1927 \mathrm{gg}$.), Which was achieved during the year, was 92 $130 \mathrm{~kg}$. Often a mass of $100 \mathrm{~kg}$ formed during 2 years of retention [3]. The logic of the search for natural methods of enhancing the efficiency of labor and increasing the shaft of commodity production has led to small individual farms of the peasants to unite in the artel, societies of joint cultivation of land, as well as the introduction of crop rotation, the use of machine-tractor technology, etc. (the regularity of this process was evidenced by the experience of others countries). The first changes in the Ukrainian village have already appeared in the 20's. However, the authorities decided to make such transformations a violent, accelerated method, at the same time alienating the peasants land ownership, means of production and depriving them of any possibility to influence the distribution of the results of their work.

Forcible collectivization, which led to the mass death of Ukrainian peasants, did not leave clear statistics even about human losses in those years, not the fall in livestock figures. So even the available official statistics on the development of rural (collectivized) economy of the 30's are significantly different.

Recall that the party's "course for continuous collectivization" was proclaimed by the Central Committee of the CPSU (b) of January 5, 1930, entitled "The pace of collectivization and state aid to collective-farm construction" [4]. Significantly, as of March 10 of the same year, $74 \%$ of all poor and 
middle-class households were collectivized in Ukraine, and in July 1931 it was proclaimed that total collectivization was generally completed.

The question of how the peasantry referred to collectivization measures, and in particular how these processes affected livestock production, is very eloquently certified by the Central Executive Committee and the Council of People's Commissars of the USSR of January 16, 1930, which strictly prohibited slaughter of cattle, which was then acquired among mass peasants. In particular, it was said: "Authorize the district executive committees to deny the right to use land, as well as to confiscate all the livestock and handicrafts of those kulaks (in fact, all peasants, not only those who were wealthy, engaged in doing this), who are livestock hunts themselves, or incline towards that other". The guilty were prosecuted and sentenced to two years' imprisonment, with eviction (or without eviction, at the discretion of the court) from the area. At the same time, the Resolution demanded: "Exclude from collective farmers who have slaughtered livestock before the introduction, and district executive committees - to issue an order for a complete prohibition of slaughter of young animals "[4]. By the decree of January 25 of the same 1930, the rural councils were obliged to "lead collectivization processes and become bodies of a lasting dictatorship in the countryside". At the same time, in the beginning of 1930, the party "mobilized" the socalled twenty-five thousandths of the party and "devoted party" workers to help the "unconscious peasantry" in the conduct of collectivization. Of those 25 thousand 10 thousand were sent to Ukraine. In addition, about 20,000 "activists" were sent from Russia to Ukraine "along the lines" of the so-called AllRussian Center for the Council of Trade Unions (OSCE) [4]. Already on February 5, an "enhanced rural asset" was ordered to collect seeds for preparation for sowing spring works in collective farms. Moreover, the collection was carried out in the form of "donuts" and "to hand over the corn had a charge every peasant, regardless of the presence of his grain" [5]. On February 15, another Resolution appeared: "Anyone who does not fulfill a rigorous task should immediately be prosecuted under paragraph 61 of the Criminal Code, with the confiscation of all property, the liquidation of his household and the exile of the kulaks themselves, which is the most realistic measure that reaches the main goal "[5]. In the conditions of all these cruel exterminations and mistreatment, on March 2 of the same 1930, the stalemated Stalin article "A Feeling of Success" was published, followed by March 14 and the corresponding Decree of the Central Committee of the Party, which "condemned" the practice of mass collectivization: "In some areas voluntarily interfere with coercion to enter the collective farm under the threat of dispossession and deprivation of voting rights. Some of the middle peasants and even the poor get into a deactivated ... There are facts of extremely brutal, brutal and criminal behavior with the peasantry ... looting, property distribution, arrests of middle peasants and even the poor ..., in some regions collectivization in a few days ranges from 10 to $90 \%$. Along with this, there are cases of compulsory socialization of residential buildings, livestock, poultry and non-market dairy cattle that are harmful to the case "[6].

The article of Stalin and its corresponding Decree of the Central Committee led to a massive escape from the collective farms. By July 1930,30.4\% of the peasant households were left in collectivization, and $39.7 \%$ were sown areas [9]. However, after the completion of the XVI Congress of the CPSU (b) in July 1930, collectivization processes unfolded rapidly, with renewed vigor. And already at the VI Congress of Soviets of the USSR in March 1931 it was proclaimed that "in front of every poor man and middleman, a single farmer who has not yet entered the collective farm, the main question is whether or not against the collective farm ... Only that poor man and middle man-single owner remains an ally of the working class, who together with it helps to build kolkhozes, who supports the collective-farm movement, who helps to resolutely fight the kulaks "[6]. In other words, all the peasants who did not enter the collective farms (even if they were poor) were considered "podkurkulnikov", and therefore enemies not only the collective farm system, but also the "power of the working people".

Since then, a real war with the Ukrainian peasantry has begun with coercion of the collective farms. This is clearly evidenced by the law of 7 August 1932 on the death penalty for theft of collective property. In the second section of the law we read: "Apply as a measure of judicial repression, for theft of the collective and cooperative property the highest measure of social protection - shooting, with the confiscation of all property. With replacement, under mitigating circumstances, the deprivation of liberty 
for a period of at least 10 years, with the confiscation of property "[9]. At the same time, the law did not set the size of the collective-farm property referred to, so people and called it the law of "three ears." Following this, on August 22, 1932, the Decree on convictions for concentration camps for 5-10 years was "for speculation and procurements", that is, the peasants also banned the sale of anything for the purchase of food. All these processes have led to a great human destruction - the Holodomor.

It is clear that under such circumstances, no reliable statistics on the "success" of management could not be. Therefore, the available figures submitted by the statistical authorities of different years are significantly different. This was paid special attention to the Ukrainian diaspora historian K.S. Kononenko In particular, with regard to the number of pigs, as of 1933, throughout the Soviet Union - at the XVII Party Congress in 1934, Stalin was named the figure - 12.2 million goals. (At the same time, this figure was compared with the number of livestock in pre-revolutionary Russia, as of 1916, and at that time the figure was 20.3 million heads of pigs). The Central Statistical Office (CSU) in 1939, concerning the same 1933 called the figure 12.1 million goals. And in 1956 (after the unfolding of the cult of Stalin) CSU in 1933 called the figure - 9.9 million goals. [6]. As for the development of pig breeding in Ukraine in the 1930's, KS Kononenko reports on the dynamics of the growth of the number of collective farms, as well as the average number of heads of pigs that belonged to one farm. So, in 1930 there were already 20,800 collective farms in Ukraine (not including those peasants who "went" and temporarily "left" from the collective farms), $38.3 \%$ of the farms and $41 \%$ of the sown area . By that time, on average, only 9.8 goals fell on each collective farm. pigs [6].

According to estimates of modern Ukrainian researchers, as of 1941 (ie, after the accession of West Ukrainian lands to the USSR), the pig population in Ukraine was approximately 9.2 million head. [7]. During the Second World War, during the years of occupation, the stock of pigs (as at the end of 1944) decreased to 2.9 million heads. and reached the pre-war level only in 1952 [7]. And in the early 1960s, dozens of state and kolkhoz tribal factories and hundreds of tribal farms worked in Ukraine. The stock of pigs in the UkrSSR amounted to 14.5 million goals. [8].

By the mid-1970s, in almost every district, 1 to 2 specialized swine farms were organized. And in a number of oblasts, industrial complexes with a completed fattening cycle of $24,36,54$, or 108 thousand head were built. pigs per year [8]. The scientists-breeders, together with the specialists of farms, extracted and tested more than 50 new high-performance plant lines and families in the breeds of pigs: large white, Mirgorod, Ukrainian steppe white, Ukrainian steppe hazel, Landrace and Wales.

The agro-industrial complex of the Ukrainian Soviet Socialist Republic in 1978 produced $23.6 \%$ of allUnion meat production [8]. The number of pigs in that year in Ukraine was 16.9 million goals. [8]. As of 1982, the number of pigs in Ukraine reached 20 million goals. [8], the population in Ukraine reached 50.3 million people. [8]. If we use the principle of the ratio used even in imperial times, then we will have almost 40 goals for every 100 people living in Ukraine. Pigs

\section{Conclusions}

At the end of the last century in Ukraine there was a powerful material and technical base for the pig breeding industry. The production of commodity pork was carried out by 5 huge industrial complexes, 650 specialist enterprises for the production of pork, a huge number of farms in collective farms, as well as in private individual farms. It is important to note separately that there was also a constant research and selection process. Breeding and improvement of breeds was carried out in 45 breeding yards, 24 pilot farmsteads and 525 pilot farms, which had the capacity to grow more than 200 thousand head per year for realization. breeding youngsters [8]. Unfortunately, this sector continues to experience a crisis situation in Ukraine today. The stock of pigs at the beginning of 2014 amounted to about 7.9 million goals. At the same time, production at state enterprises is about $10 \%$ of pork production, in collective reformed farms $-24 \%$, in farms - about 1 , in individual $-65 \%$.

Moreover, the possibility of further growth in private households is practically exhausted, because they are not supported at the proper level by the state. So now, the pig industry needs an updated state strategy for development. 


\section{Bibliography}

1. Agro-industrial complex of the Ukrainian SSR (improvement of the organizational-production structure) / A.M. Onishchenko, AV Zharikov, Yu.I. Sopilniak et al. - K .: Science. opinion, 1980. - 197 p.

2. All-Union census of the population of 1926. - In $10 \mathrm{t}$. - Moscow: The edition of the CSU of the USSR, 1927 - 1929. - Issue. 3: The population of the USSR. - 1927. - 63 p.

3. History of the Ukrainian peasantry. - Essays in 2 volumes / O.V. Androschuk, V.K. Baran, O.M. Veselova and others. - K .: Science. thought, 2006. - T. 2. - 653 p.

4. Kalinichenko VV Peasant economy of Ukraine in the pre-farm period (1921 - 1929) N.V. Kalinichenko - Kh. Osnov, 1991. - 131 p.

5. Kononenko K.S. Ukraine and Russia. Socio-economic foundations of the Ukrainian national idea. 1917 - 1960 / K.S. Kononenko - Munich, 1965. - 535 p.

6. The national economy of the USSR. 1922 - 1982: Anniversary Statistical Yearbook / USSR CSU. Moscow: Finances and Statistics, 1982. - 624 pp.

7. Malienko A. Problems of Agrarian Reforms in Ukraine // Dzerkalo Tyzhnya. - August 2000. - No. 32 (305).

8. Gaidutsky P.I. Agrarian Reform in Ukraine / P.I. Gaiduckiy, P.T. Sabluk, Yu.O. Lupenko - K.: NSC IAE, 2005. - 424 p.

9. Gorlenko VF National Agricultural Technique of Ukrainians (Historical and Ethnographic Monograph) / V.F. Gorlenko, I.D. Boyko, O.S. Kunytsky - K .: Science. thought, 1971. - 164 pp.

10. Agriculture of Ukraine from the past to the present. - T. 1. - K .: Agrar. science, 2005. - 380 pp. 